\title{
Turkish Student's Perception about the Black Body Radiation, Photoelectric Effect and Compton Scattering Phenomena
}

\author{
Gunay Palic Sadoglu (Corresponding author) \\ Recep Tayyip Erdogan University, Faculty of Education, Department of Primary Education \\ 53100, Rize, Turkey \\ Tel: 90-464-532-8454Ｅ-mail: gunay.palic@erdogan.edu.tr
}

Ali Riza Akdeniz

Karadeniz Technical University, Fatih Faculty of Education

Department of Secondary Science Education, 61000, Trabzon, Turkey

Received: Feb.22, 2015 Accepted: August30, 2015 Published: August 30, 2015

doi:10.5296/jse.v5i3.8109 URL: http://dx.doi.org/10.5296/jse.v5i3.8109

\begin{abstract}
The goal of this study is to research Turkish student's perception in the black body radiation, photoelectric effect and compton scattering phenomena. 2611 th grade students receiving education at a Turkish high school participated in the study. The black body radiation, photoelectric effect and compton scattering subjects were carried out throughout a 4 week period in 16 academic hours in accordance with the constructivist learning theory. 7 open-ended questions were applied as pre-study and post-study. This study is a descriptive research. Content analysis method was used in the study. While majority of students defined the black body as 'a body that cools down the light falling upon it' during the post-study, they gave examples of objects with black exterior and that these examples could not represent the black body radiation. Students could not identify the metal plates as anode and cathode in photocell circuit, so they could not predict the direction of current in photocell circuit correctly. Also, students had a misconception that light intensity is the light energy and, therefore, with the increase of light intensity, the kinetic energy of snatched electrons would increase and they would reach the plate faster.
\end{abstract}

Keywords: Black body radiation, Photoelectric effect, Compton scattering, Turkish student 


\section{Introduction}

Despite the fact that positive effect of relation between science and math teaching and daily life on the learning process of concepts and processes is being emphasized, it is known that many teaching methods nowadays relate little to the daily life. This situation gives rise to a teaching approach in the form of exact reflecting of the knowledge and memorization based activities (Cam, 2008). In other words, knowledge cannot be sufficiently structured by available learning processes; it cannot be conveyed to real life experiences. It is stated that concepts of the High School Physics Academic Program should be presented by making relations to the real life and students should be provided with an opportunity to interpret and resolve the events encountered in daily life using the knowledge obtained from the class. Significant learning during the physics class can be performed in a learning environment that ensures the verification of students' prior knowledge, is based on context encountered in real life, is cognitively and physically active and provides conceptual changes. In this regard, a solution can be expressed in the need for creating a practice based on a constructivist learning theory that would encourage cognitive and physical participation by students, verify their prior knowledge, include laboratory experiments and class activities that bring individual differences to the foreground that could be benefited from and implemented by the teachers in classrooms.

In a physics class, besides the situation of being able or unable to learn a certain concept, there is a situation of learning said concept wrong and embracing the incorrect concept with time, thus transforming it into a misconception. This case prevents meaningful and permanent learning. Therefore, in order to correctly teaching a concept, the prior information and misconceptions of students, if any, should be strictly identified and the teaching process should be planned with these in consideration (Psillos, Koumaras \& Tiverhien, 1988; Beasley, 2005). In this regard, the constructivist learning model emphasizes the consideration of students' prior knowledge and identification of such knowledge in terms of validity, correctness and misconceptions. The constructivist learning model based on the idea developed by Wittrock and expressed by Ausubel as "the important factor that affects learning is a student's available knowledge" can be seen by us a learning model that attempts to define the acquisition of new knowledge by students using their prior knowledge, the learning process and creation of specific knowledge (Hand \& Treagust, 1991; Turgut et al., 1997; Appleton, 1997). In other words, the constructivist learning model focuses on the idea that knowledge is formed by the learner, every student is gaining new knowledge acquired from the environment by relating it to their available prior knowledge (Cepni, Ayas, Ekiz \& Akyildiz, 2010).

Blackbody Radiation (Planck, 1900), Photoelectric Effect (Einstein, 1905), and Compton Scattering (Compton, 1923) phenomena indicate evidence about that light consists of particles called photons. These phenomena led to emergence of the modern quantum theory. Additionally, it is thought that the subjects of modern physics, being one of the High School 11th grade study units, are more abstract in comparison to other physics subjects and therefore more difficult to learn. Akdeniz and Palic (2012) determined that modern physics topics are carried outsuperficially. It is noted that modern physics topics cannot related to everyday life and therefore there are difficulties in teaching the modern physics topics. 


\section{Mll Macrothink}

Literature shows that studies on identifying the misconceptions of students in relation to quantum physics concepts and more effective teaching and learning of quantum physics concepts has become an area that attracts the interest of physics education researchers in the past years (Ayvaci, 2013; Caliskan, Selcuk \& Erol, 2009; Escalada, 1997; Ozcan, 2011; Ozdemir \& Erol, 2011; Sadaghiani, 2005; Sen, 2002; Vadnere\& Joshi, 2009; Yildı, 2009; Yildiz \& Buyukkasap, 2011a; Yildiz \& Buyukkasap, 2011b). Such studies determined that students perceive the quantum lessons as difficult and hard to understand (abstract), that quantum concepts are not learned sufficiently and the learned concepts were not permanent (Didis, Ozcan \& Abak, 2008; Didis, Eryilmaz \& Erkoc, 2010; Ozcan, 2011; Steinberg, Wittman, Bao \& Redish, 1999; Singh, 2001; Singh, Belloni \& Christian, 2006; Zhu, 2011). The complex mathematical infrastructure, abstract and non-parallel to each other concepts of the quantum physics were determined to be among the difficulties experienced in learning the subject (Akarsu, 2007; Akarsu 2011; Didis, Eryilmaz \& Erkoc, 2010). For most students quantum physics is defined as based only on mathematical formulas and difficult to understand (Styer, 1997). As a result, it is noted that under the effect of many misconceptions, students exhibit very low rate of success (Didis, Ozcan \& Abak, 2008; Singh, Belloni \& Christian, 2006; Styer, 1997; Yildiz \& Buyukkasap, 2011a). Studies, performed in relation to the subjects of photoelectric effect and Compton scattering, researched the effect of learning intended writing activities which had affected the academic success rate of science teacher candidates (Yesildag, 2009; Yildiz, 2009; Yildiz \& Buyukkasap, 2011a; Yildiz \& Buyukkasap, 2011b).

The goal of this study is to research perception of $11^{\text {th }}$ high school Turkish students in the black body radiation, photoelectric effect and Compton scattering phenomena.

\section{Method}

This study was conducted with descriptive study of research method. According to Kaptan (1998), the research which tries to identify some events, objects, entities, associations, groups and various fields are descriptive studies. Descriptive studies aim at explaining the interaction between the situations, by taking care of existing events and the previous events and their relations.

26 11th grade students receiving education at a Turkish high school participated in the study. Modern Physics Unit containing blackbody radiation, photoelectric effect, and Compton scattering were taught in accordance with the constructivist learning theory. The study was carried out throughout a 4-week period in 16 academic hours.

\subsection{Data Collection Tool}

7 open-ended questions were applied as pre-study and post-study. The open-ended questions are presented in the following.

Q.1. Draw a black body model. Explain why your drawing is a black body.

Q.2. Give at least 3 examples of black body radiation from your environment and explain why they constitute examples for the black body radiation.

Q3. Below is an alarm system. Explain how this circuit works. 


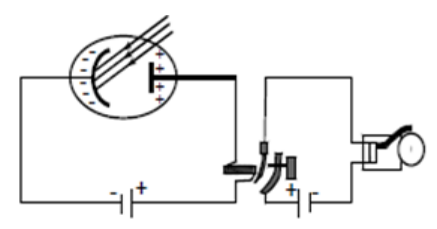

Q4.Indicate and explain the type of metal plate used, surface area, inter-plate gap, voltage applied to the circuit, and the light intensity variables necessary to be changed in order to increase the current forming in the circuit.

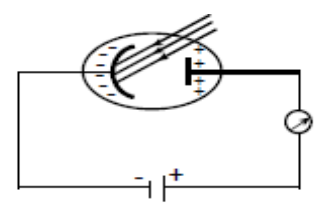

Q5. Draw the situation of a high energy photon colliding with a free electrode. Define the scientific occurrence that can explain this situation.

Q6.Compare the energy, frequency, wavelength, velocity, and momentums of photon and electron before and after the collision. What can you say regarding the total energy and total momentum?

Q7. The table below indicates how classical physics, black body radiation, photoelectric effect and Compton scattering are explained. What is the approach of modern physics with these situations?

\begin{tabular}{|c|c|}
\hline & Classical physics \\
\hline \multirow{2}{*}{$\begin{array}{l}\text { Black body } \\
\text { radiation }\end{array}$} & As the wavelength of the light decreases, its intensity increases towards the infinity. \\
\hline & Photon's energy increases as light intensity increases. \\
\hline \multirow{2}{*}{$\begin{array}{l}\text { Photoelectric } \\
\text { effect }\end{array}$} & $\begin{array}{l}\text { As the light intensity increases, the photoelectrons snatched from the metal surface will have } \\
\text { greater kinetic energy. }\end{array}$ \\
\hline & $\begin{array}{l}\text { There is no frequency, which is energy limit for the electromagnetic waves sent to the metal } \\
\text { surface in order to snatch electrons from the surface and that every frequency value is able to } \\
\text { snatch electrons from the surface. }\end{array}$ \\
\hline \multirow[t]{2}{*}{$\begin{array}{l}\text { Compton } \\
\text { scattering }\end{array}$} & $\begin{array}{l}\text { Electrons begin to vibrate under the effect of electric field of the electromagnetic wave } \\
\text { reaching the metal surface, and the vibrating electrons (due to inertial movement) diffuse new } \\
\text { electromagnetic waves in various directions. }\end{array}$ \\
\hline & $\begin{array}{l}\text { It is also indicated that the wavelength of the dispersed electromagnetic wave is equal to the } \\
\text { incoming beam's wavelength. }\end{array}$ \\
\hline
\end{tabular}

\subsection{Data Analysis}

In this study, a content analysis was conducted on students' open-ended question responses. The basic purpose of the content analysis is to explain the concepts and relationships in the collected data (Yildirim \& Simsek, 2006).

Students' open-ended question responses were analyzed according to the following rubric. 
Table 1. The rubric

\begin{tabular}{ll}
\hline Category & Definition \\
\hline CCD & including completely correct definitions \\
\hline ID & including correct but incomplete definitions \\
\hline ED & including correct as well as incorrect definitions \\
\hline CED & including completely wrong definitions \\
\hline ND & has no response or definitions that are not relating to the question \\
\hline * 'CCD'; It means that the completely correct definition. 'ID'; It means that the incomplete definition. 'ED'; It \\
means that the erroneous definition. 'CED'; It means that the completely erroneous definition. 'ND'; It means \\
that no definition.
\end{tabular}

that no definition.

\section{Findings}

This section contains the answers provided by students to open-ended questions. Students' responses in pre-post study related to the $1^{\text {st }}$ question are presented in Table 2 .

Table 2. Students' responses to 1st question of pre-post study

\begin{tabular}{|c|c|c|c|c|c|}
\hline & & Category & Students (f) & Example Quote & Example Drawing \\
\hline \multirow{6}{*}{ 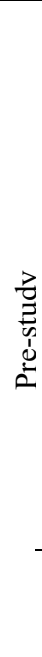 } & \multirow{5}{*}{ 先 } & $\mathrm{CCD}$ & - & - & - \\
\hline & & ID & 1 & $\begin{array}{l}\text { S19: Round } \\
\text { A body that cools down the light falling upon it } \\
\text { and therefore seeming to be darker }\end{array}$ & \\
\hline & & ED & 5 & $\begin{array}{l}\text { S22: Round } \\
\text { A body with dark exterior }\end{array}$ & \\
\hline & & CED & 14 & $\begin{array}{l}\text { S3: Scribble (no geometric shape) } \\
\text { A body darkened due to the excessive radiation }\end{array}$ & \\
\hline & & ND & - & - & - \\
\hline & $\begin{array}{l}\text { No } \\
\text { drawing }\end{array}$ & ND & 6 & - & - \\
\hline \multirow{8}{*}{ 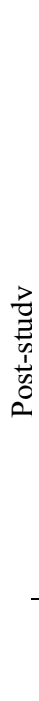 } & \multirow{7}{*}{ 苛 } & $\mathrm{CCD}$ & 10 & S12: Cube (box) & \\
\hline & & & & $\begin{array}{l}\text { A body that cools down the absorbed radiation } \\
\text { and does not let it out (does not reflect) }\end{array}$ & \\
\hline & & ID & 14 & S18: Round & \\
\hline & & & & A body that cools down the light falling upon it & \\
\hline & & ED & 2 & $\begin{array}{l}\text { S16: Cube (box) } \\
\text { A body with dark exterior }\end{array}$ & \\
\hline & & CED & - & - & - \\
\hline & & ND & - & - & - \\
\hline & $\begin{array}{l}\text { No } \\
\text { drawing }\end{array}$ & ND & - & - & - \\
\hline
\end{tabular}


The pre-study shows that one student provided an incomplete definition of why the drawn model was a black body, five students provided an erroneous definition, and fourteen students did not provide a definition, and six students were unable to make a drawing. It was determined that students had round, squared, scribble (no geometric shape), and rectangular models to represent the black body but most students used the round shape. It is seen that majority of students define the black body as "a body with dark exterior".

The post-study shows that ten students provided completely correct explanation of why their model is a black body, fourteen students provided incomplete explanation, two students provided erroneous explanation. It was observed that students drew the black body model in their post-study as round, scribble (no geometric shape), cube (box) and triangular shapes but majority drew the round shape.

Table 3. Students' responses to 2nd question of pre-post study

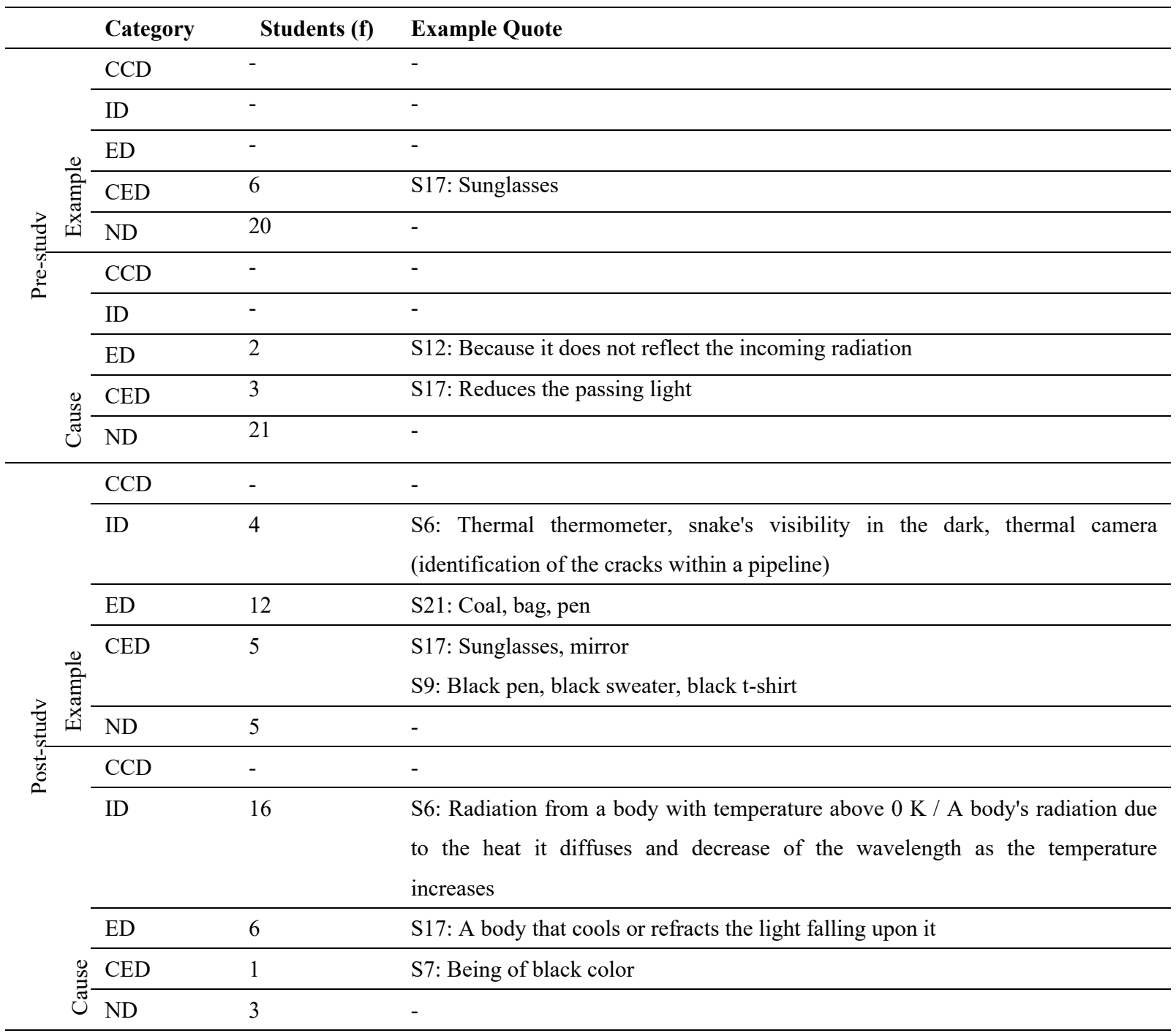

In pre-study, it has been observed that there are six students, who gave completely erroneous example of black body radiation, and twenty students, who did not give any examples. There are also two students, who provided wrong explanation of why their examples are examples 
of black body radiation, and three students, who provided completely wrong explanation. Furthermore, some of the students' erroneous answers were "a body unreachable by light", "a body that entered and is unable to escape from the black hole", a body that darkened as a result of radiation", "a body that separated from the black hole". Among the responses of students related to the definition of a black body, there were such incomplete explanations as "a body that cools down the incoming light and thus seems to be dark". Some of the examples provided by students for black body definition were such completely incorrect explanations as "sunglasses, space, black pen, black sweater, black t-shirt". Responses of students, regarding the reason for their examples being as examples of a dark body, contained such completely incorrect expressions as "light is reflected when it hits a dark body", "weakens and passes the incoming light", visible during the day but invisible during the night".

It was observed that students drew the black body model in their post-study as round, scribble (no geometric shape), cubical (box) and triangular shapes but majority of students drew the round shape. Students were found to give incomplete or erroneous responses regarding the black body. Majority of students were found to define the black body as a body that cools down the light falling upon it, a body that cools down the absorbed radiation and does not let it out. It is seen that most examples provided by the students are objects with black color. An example of correct explanations provided by students regarding the definition of a black body can be the expression "a body that cools down the absorbed radiation and does not let it out". An example of erroneous explanations can be the notion "an object with dark exterior" and "a well cooling and well reflecting object". It is also observed that four students provided incomplete examples to the black body radiation, twelve students provided erroneous examples, five students provided completely incorrect examples, and five students were unable to provide examples. An erroneous example of black body given by the student can be the one provided by student S17 "sunglasses, mirror". As well as the examples given by student S9 "black pen, black sweater, black t-shirt".

There are also sixteen students, who provided incomplete explanation of why their examples are examples of black body radiation, six students, who provided erroneous explanation, and one student, who provided completely wrong explanation. An example of incomplete explanation provided by the students can be "radiation by anybody with temperature above 0 $\mathrm{K} / \mathrm{a}$ body's radiation due to the heat it diffuses and decrease of the wavelength as the temperature increases". "A body that cools down or reflect the light falling upon it" can be presented as an erroneous explanation, whereas the example of a completely incorrect explanation can be the expression "being of black color". 
Table 4. Students' responses to 3rd question of pre-post study

\begin{tabular}{lll} 
Category & Students (f) & Example Quote \\
\hline ID & - & -
\end{tabular}

During the pre-study, thirteen students gave an explanation to the operation of the circuit and these explanations were found to be incomplete and incorrect. The five students gave an incomplete explanation of the alarm circuit operation, and eight students gave an erroneous explanation. It can be seen that majority of students attempted to explain the circuit based on the light energy using such expressions as "the incoming light creates a magnetic field between + and -, the rod moves and the alarm rings", "electrons are driven by the light energy and the battery operates the alarm", electrons are driven by the light energy, the bobbin becomes an electromagnet and the alarm rings", "beams transition from the - load to the + load and the alarm rings", "the bobbin becomes an electromagnet due to high-energy beams, pulls the rod and the alarm rings".

In post-study, four students provided completely correct explanation of how the alarm circuit operates, sixteen students provided incomplete explanation, four students provided erroneous explanation, one student provided completely incorrect explanation, and one student was unable to provide an explanation. Most students were found to be unable to give a complete explanation of the circuit. Also, students indicated that when the light reaches the photocell lamp, the magnetic field occurring in the bobbin due to the current formed in the circuit pulls or pushes the rod and the alarm will ring. 
Table 5. Students' responses to 4th question of pre-post study

\begin{tabular}{|c|c|c|c|c|}
\hline & & Category & Students (f) & Example Quote \\
\hline \multirow{10}{*}{ 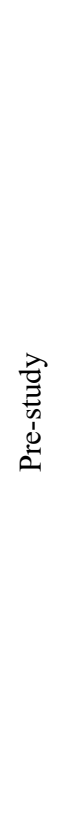 } & \multirow{5}{*}{ 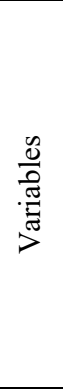 } & $\mathrm{CCD}$ & - & - \\
\hline & & ID & 1 & $\begin{array}{l}\text { S22: The surface area of the plate should be increased, inter-plate gaps should } \\
\text { be decreased, light intensity increased, voltage increased }\end{array}$ \\
\hline & & $\mathrm{ED}$ & 14 & $\begin{array}{l}\text { S13: Inter-plate gap should be decreased, plate surface area decreased, light } \\
\text { intensity increased, voltage increased }\end{array}$ \\
\hline & & CED & - & - \\
\hline & & ND & 11 & - \\
\hline & \multirow{5}{*}{ 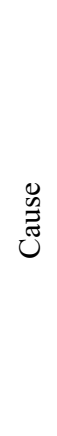 } & $\mathrm{CCD}$ & - & - \\
\hline & & ID & - & - \\
\hline & & ED & 3 & $\begin{array}{l}\text { S6:The light intensity increases as the conductor wire diameter increases, the } \\
\text { light intensity increases as the wire length decreases, the light intensity } \\
\text { increases as the voltage increases, the wire type should be of the copper nickel } \\
\text { composition in order to increase the conductivity }\end{array}$ \\
\hline & & CED & - & - \\
\hline & & ND & 23 & - \\
\hline
\end{tabular}

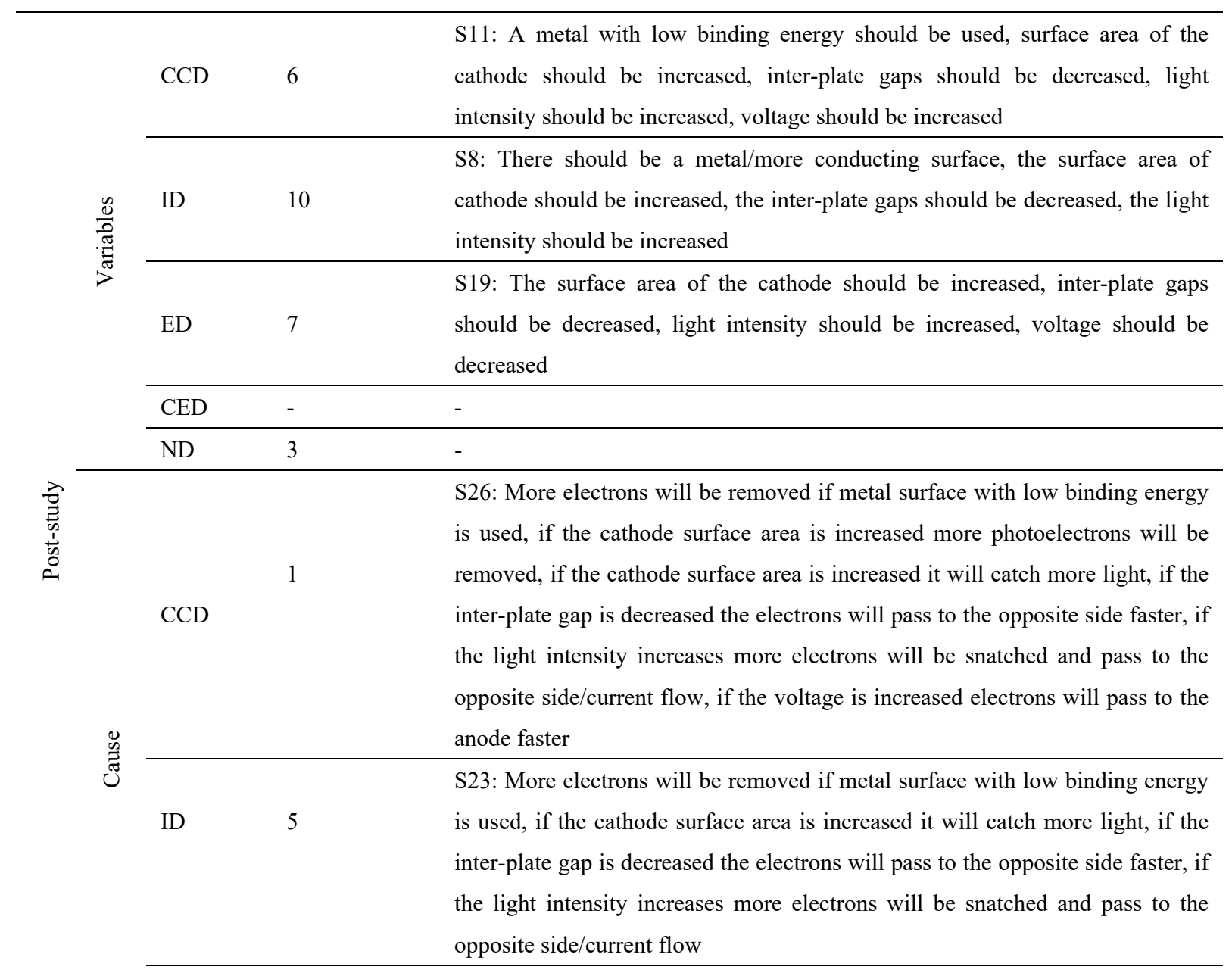

S9: If the cathode surface area is increased it will catch more light, if the inter-plate gaps are decreased the electrons will pass to the opposite side faster, 
if the light intensity increases more electrons will be snatched and conveyed to the opposite side/current flow, if the voltage is increased the number of snatched electrons decreases and the current drops

\begin{tabular}{lll}
\hline CED & - & - \\
\hline ND & 10 & -
\end{tabular}

In pre-study, it can be seen that the explanations provided by students in relation to changes necessary to be applied to the variables of the type of metal plate used, inter-plate gap, voltage applied to the circuit and light intensity in order to increase the current in the circuit contained incomplete or incorrect expressions. "Plate surface area should be increased", "inter-plate gap should be increased", "voltage should be decreased" are among the erroneous expressions within the explanations provided by students. It is seen that only three of the students provided definitions in relation to the justification and these explanations contained erroneous expressions. For instance, students S6 gave the following incorrect definitions "light intensity increases as the conductor wire diameter increases", "light intensity increases as the wire length decreases", "light intensity increases as the voltage increases".

In post-study, six students provided correct explanation, ten students provided an incomplete explanation, seven students provided erroneous explanations and three students did not provide an explanation. One student gave correct explanation of the indicated basis, five students gave an incomplete explanation, ten students gave an erroneous explanation and ten students did not provide an explanation. Some of the erroneous expressions seen among the responses of students are as follows, "if the voltage is increased the number of snatched electrons decreases and the current drops", "decrease in voltage causes decrease in resistance and easier passing of electrons to the opposite side", "if the light intensity increases, photons with small wavelength will come and snatch electrons more easily", "if the inter-plate gap is decreased, more electrons will be snatched", "if voltage increases the number of snatched electrons increased". 
Table 6. Students' responses to 5th question of pre-post study

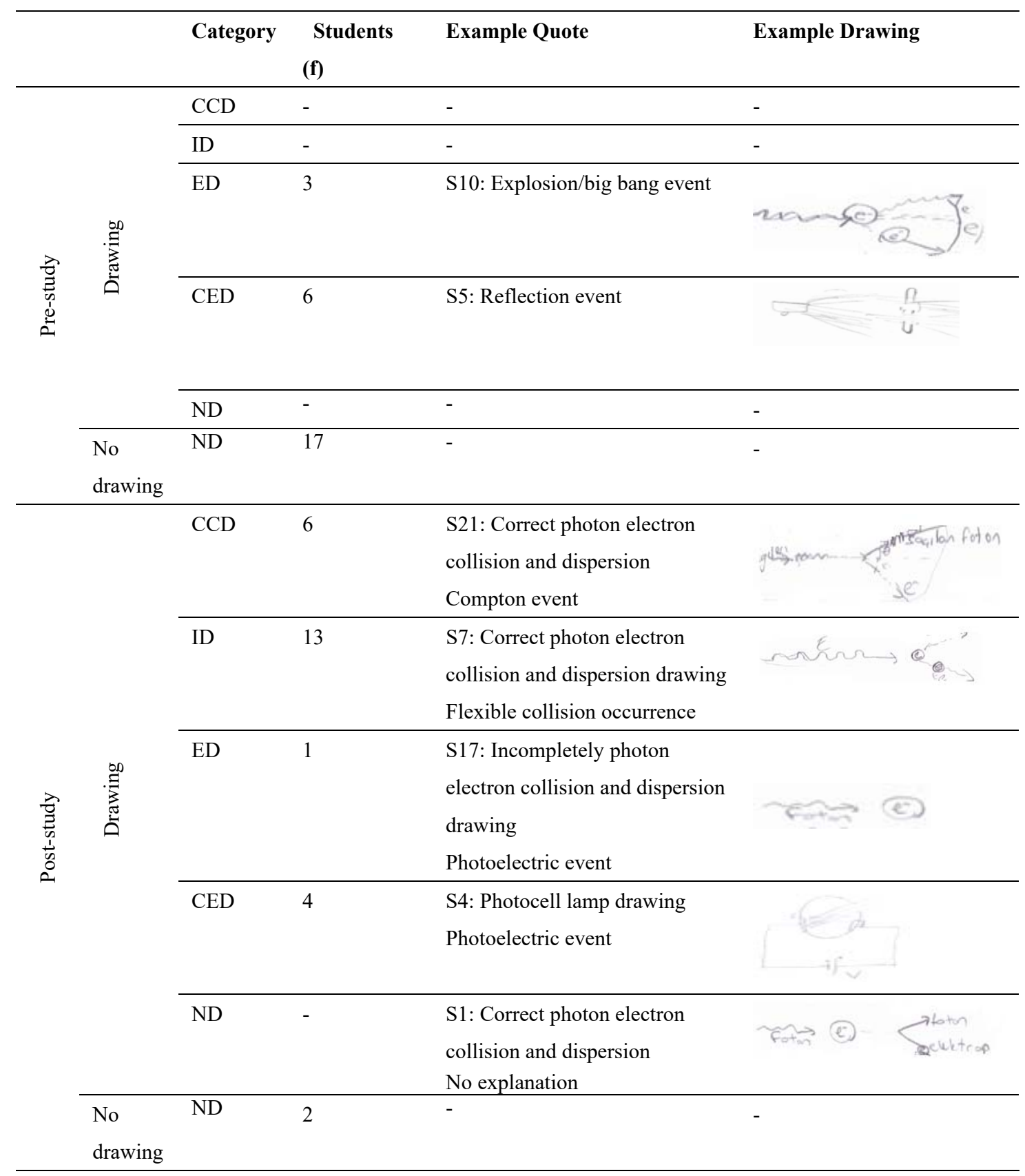

In pre-study, the three students gave an erroneous explanation to the model drawn, six students provided completely incorrect explanation and seventeen students did not make any drawing during pre-study. It was observed that students drew the case of collision of high-energy photon to a free electron incompletely or incorrectly. Whereas the students explained their drawings as "non-flexible collision event", "explosion/big bang event", "radiation event", bing bang event".

In post-study, students drew the case of collision of high-energy photon to a free electron correctly, incompletely or incorrectly during the post-study. The six students provided correct explanation of the model drawn, thirteen students provided incomplete explanation, one student provided erroneous explanation, and two students did not make any drawing. 
Table 7. Students' responses to 6th question of pre-post study

\begin{tabular}{|c|c|c|c|}
\hline & Category & $\begin{array}{l}\text { Students } \\
\text { (f) }\end{array}$ & Example Quote \\
\hline \multirow{5}{*}{ 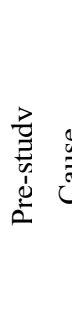 } & $\mathrm{CCD}$ & - & - \\
\hline & ID & - & - \\
\hline & ED & 7 & $\begin{array}{l}\text { S10: Photon's energy increases, photon's frequency decreases, photon's wavelength } \\
\text { decreases, electron's speed increases }\end{array}$ \\
\hline & CED & - & - \\
\hline & ND & 19 & - \\
\hline \multirow{5}{*}{ 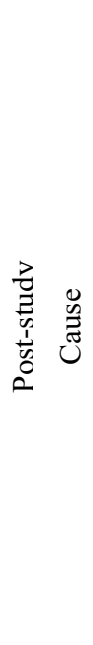 } & $\mathrm{CCD}$ & 2 & $\begin{array}{l}\text { S3: Photon's energy decreases, photon's frequency decreases, photon's momentum } \\
\text { decreases, photon's wavelength increases, photon's velocity constant, electron's } \\
\text { energy increases, electron's momentum increases, electron's velocity increases, total } \\
\text { momentum and energy is retained }\end{array}$ \\
\hline & ID & 2 & $\begin{array}{l}\text { S10: Photon's energy decreases, photon's frequency decreases, total momentum and } \\
\text { energy is retained }\end{array}$ \\
\hline & ED & 16 & $\begin{array}{l}\text { S6: Photon's energy increases, photon's frequency increases, photon's momentum is } \\
\text { constant, electron's velocity is constant, total momentum and energy is retained }\end{array}$ \\
\hline & CED & 1 & $\begin{array}{l}\text { S24: Photon's energy increases, photon's velocity decreases, photon's wavelength } \\
\text { decreases, photon's momentum increases, photon's frequency increases, photon's } \\
\text { energy increases }\end{array}$ \\
\hline & ND & 5 & - \\
\hline
\end{tabular}

In pre-study, it is seen that seven students gave erroneous explanation and nineteen students did not give an explanation for the energy, frequency, wavelength, velocity, momentum, total energy and total momentum. It is determined that students' responses contain such erroneous expressions as the photon wavelength will decrease, photon velocity will increase, photon energy will increase, photon velocity will decrease, photon frequency will increase.

In post-study, two student was able to provide correct explanation for the post photon and electron collision energy, frequency, wavelength, velocity, momentum, total energy and total momentum, two students provided incomplete explanation, sixteen students provided erroneous explanation, one student provided completely incorrect explanation, and five students were unable to provide an explanation. Explanations made by students contain correct expressions such as that photon's energy will decrease, photon's frequency will decrease, total momentum and energy will be retained, photon velocity will be unchanged, photon momentum will decrease, photon wavelength will increase, electron energy will increase, electron momentum will increase, and electron velocity will increase. 
Table 8. Students' responses to 7th question of pre-post study

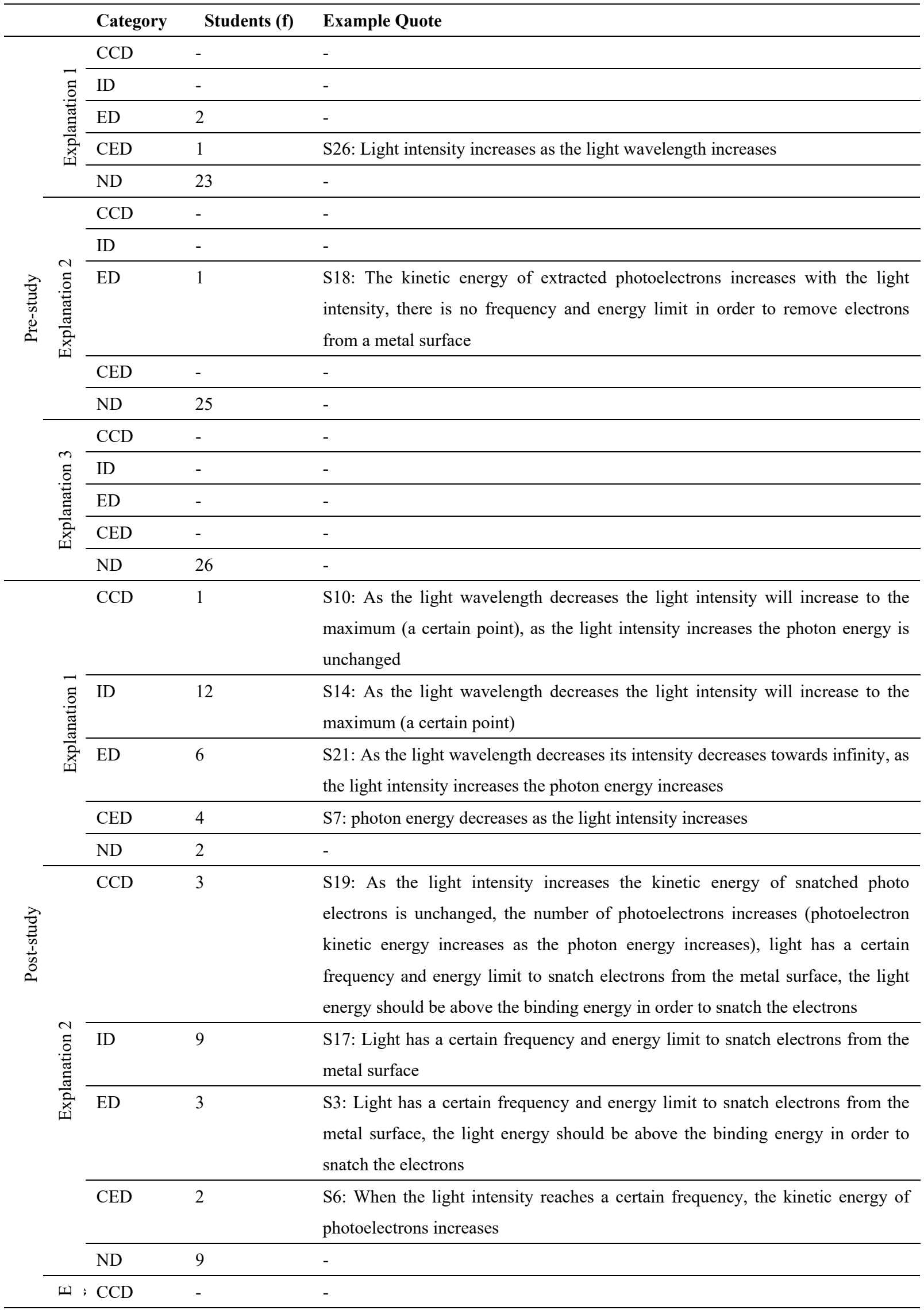




\begin{tabular}{lll} 
ID & 9 & S11: The wavelength of dispersed photons increases \\
\hline ED & - & - \\
\hline CED & 6 & $\begin{array}{l}\text { S13: The wavelength of dispersed photons is smaller than the wavelength of } \\
\text { incoming photons }\end{array}$ \\
\hline ND & 11 & -
\end{tabular}

In pre-study, two students gave erroneous definitions of the black body radiation in terms of modern physics approach against the views indicated in classic physics, one student gave a completely incorrect definition, twenty three students did not give any definition. Explanations of S10 and S11 "the intensity of light decreases towards the infinity in proportion to the decrease in the light wavelength" can be given as an example of erroneous definitions made by the students. The twenty five students did not give any definition of the black body radiation in terms of modern physics approach against the views indicated in classic physics, and twenty six students were unable to give an explanation in terms of modern physics approach against the views indicated in classic physics regarding the Compton event.

In post-study, the students provided limited explanations and these explanations contain correct, incomplete or erroneous expressions. One student gave correct explanation of the modern physics approach against the views indicated in classic physics regarding the black body radiation, twelve students provided incomplete explanation, six students provided erroneous explanation, four students provided completely incorrect explanation, and two students were unable to provide an explanation. The expression "as the light wavelength decreases the light intensity will increase to the maximum (a certain point), as the light intensity increases the photon energy is unchanged" by student S10 can be given as an example of correct explanation. An example of erroneous definition given by students can be the expression of student S21 "photon's energy increases as the light intensity does". Three students gave correct explanation of the modern physics approach against the views indicated in classic physics regarding the photoelectric event, nine students provided incomplete explanation, three students provided erroneous explanation, two students provided completely incorrect explanation, and nine students were unable to provide an explanation. An example of erroneous definition given by students can be the expression of student S3 "kinetic energy of extracted photoelectrons increases with the light intensity". Nine students gave incomplete explanation of modern physics approach against the views indicated in classic physics regarding the Compton event, six students provided completely incorrect explanation, and eleven students were unable to provide explanation. An example of completely incorrect explanations given by students can be the expression of student S13 "the wavelength of dispersed photons is smaller than the wavelength of incoming photons".

\section{Discussion and Conclusion}

Students indicated during the post-study that various shapes such as round, scribble, cubic and triangular can be used for the black body model; however, generally the round shape was used. During the exploration stage of the procedure, an activity was implemented to conclude that black body radiation is not based on the shape by creating round, square and rectangular 
models of various sizes for the black body model. While majority of students defined the black body as "a body with dark exterior" during the pre-study, they defined it as "a body that cools down the light falling upon it" during the post-study. Additionally, they made explanations during the post-study that the radiation of a black body is invisibly because it occurs in the invisible section, that the radiation of a black body depends on the temperature that radiation intensity increases as the temperature of the black body increases. Nevertheless, it was found that they gave examples of objects with black exterior and that these examples could not represent the black body radiation. This condition is thought to be caused by the black body models created during the activity of the exploration stage of the application for the black body radiation.

Students were seen to make attempts to define the electric circuit without the explanation of the photocell lamp operation principle during the pre-study. Most students were found to be unable to give a complete explanation of the circuit during the post-study. Students indicated that when the light reaches the photocell lamp, the magnetic field occurring in the bobbin due to the current formed in the circuit pulls or pushes the rod and the alarm will ring. Additionally, a misconception, the current in the circuit would increase as the voltage decreased, was determined. This case can be said to be caused by the fact that students thought a producer in the circuit to be connected in reverse. This case can be said to relate to in-class practices. Students could not identify the metal plates as anode and cathode in photocell circuit (Garnett \& Treagust, 1992; Ercan, 2010; Karsli, 2011; Karsli \& Calik, 2012; Sanger \& Greenbowe, 1997, 1999), so they could not predict the direction of current in photocell circuit correctly. In this case, students may have thought that the generator is connected in reverse the circuit photocell.

Post-study revealed that students had a misconception that light intensity is the light energy and, therefore, with the increase of light intensity, the kinetic energy of snatched electrons would increase and they would reach the plate faster. This situation during the post-study was interpreted to be caused by the simulation activity during the exploration stage of the application. During the exploration stage of the application it can be indicated that there is no relation between the use of same frequency light with increasing intensity and then same light intensity with different frequencies and the velocity of snatched electrons and the light intensity. Students were found to indicate that the photon velocity would change after the collision. "The velocity of incoming marble decreased due to the passing of a portion of its energy to the target marble" result was obtained during the colliding marbles activity of the application. It is thought that a wrong perception of the fact that because the marble is considered to be a photon and that the marble's velocity would decrease after the collision with the target marble, therefore the photon's speed would also decrease. This situation can be caused by the example provided. Moreover, the post-study determined that there are students stating that the electron velocity would be unchanged. This situation can be caused by the fact that students consider the electron to be a photon. Mashhadi \& Woolnough (1999) found that high school students had very various and non-scientific representation of electrons and photons in their minds and majority of students see the electron as a kind of particle, while seeing the photon as a bright and round particle. Olsen (2001) determined that 
high school students did not understand the structure of an electron and a photon. Caliskan, Selcuk \& Erol (2009) determined in their study that students think of the electron as a wave or a particle.

\section{References}

Akarsu, B. (2007). Students' misconceptual understanding of quantum physics in college level classroom environments. Unpublished doctoral thesis, Indiana University, USA.

Akarsu, B. (2011). Instructional design in quantum physics: a critical review of research. Asian Journal of Applied Sciences, $4(2), \quad 112-118$. http://dx.doi.org/10.3923/ajaps.2011.112.118

Akdeniz, A. R., \& Palic, G. (2012) Yeni fizik ogretim programina ve uygulanmasina yonelik ogretmen gorusleri. Milli Egitim Dergisi, 196, 290-307.

Appleton, K. (1997). Analysis and description of students' learning during science classes using a constructivist based model. Journal of Research in Science Teaching, 34(3), 303-318. http://dx.doi.org/10.1002/(SICI)1098-2736(199703)34:3<303::AID-TEA6>3.0.CO;2-W

Ayvaci, H. S. (2013). Investigating the effectiveness of predict-observe-explain strategy on teaching photo electricity topic. Journal of Baltic Science Education, 12(5), 548-564.

Caliskan, S., Sezgin Selcuk, G., \& Erol, M. (2009). Student understanding of some quantum physical concepts.Latin American Journal of Physics Education, 3(2), 202-206.

Cam, F. (2008). Biyoloji derslerinde yasam temelli ogrenme yaklasimin etkileri, Yayimlanmamis yuksek lisans tezi, Ataturk Universitesi, Erzurum.

Cepni, S., Ayas, A., Ekiz, D., \& Akyildiz, S. (2010). Ogretim ilke ve yontemleri.Trabzon: Celepler Matbaacilik.

Didis, N., Ozcan, O., \& Abak, M. (2008). Ogrencilerin bakis acisiyla kuantum fizigi: nitel calisma. Hacettepe Universitesi Egitim Fakultesi Dergisi, 34, 86-94.

Didis, N., Eryilmaz, A., \& Erkoc, S. (2010). Pre-service physics teachers' comprehension of quantum mechanical concepts. Eurasia Journal of Mathematics, Science \& Technology Education, 6(4), 227-235.

Ercan, O. (2010). Ogretmenlerin elektrokimya konularindaki kavram yanilgilari, Turkiye Sosyal Arastirmalar Dergisi, 1, 111-134.

Escalada, L. T. (1997). Investigating the applicability of activity-based quantum mechanics in a few high school physics classrooms. Unpublished doctoral thesis, Kansas State University, Kansas.

Garnett, P.L., \& Treagust, D.F. (1992). Conceptual difficulties experienced by senior high school students of electrochemistry: electrochemical (galvanic) and electrolytic cells. Journal of Research in Science Teaching, 29(10), 1079-1099. http://dx.doi.org/10.1002/tea.3660291006 
Hand, B., \& Treagust, D. F. (1991). Student achievement and science curriculum development using a constructivist framework. School Science and Mathematics, 91(4), 172-176. http://dx.doi.org/10.1111/j.1949-8594.1991.tb12073.x

Kaptan, S. (1998). Bilimsel arastirma ve istatistik teknikleri. Ankara: Tekisik Web Ofset Tesisleri.

Karsli, F. (2011). Fen bilgisi ogretmen adaylarinin bilimsel surec becerilerini gelistirmesinde ve kavramsal degisim saglamasinda zenginlestirilmis laboratuar rehber materyallerinin etkisi.Yayimlanmamis doktora tezi, Karadeniz Teknik Üniversitesi, Trabzon.

Karsli, F., \& Calik, M. (2012). Can freshman science student teachers' alternative conceptions of 'electrochemical cells' be fully diminished? Asian Journal of Chemistry, 23(12), 485-491.

Mashhadi, A., \& Woolnough, B. (1999). Insights into students' understanding of quantum physics: visualizing quantum entities. European Journal of Physics, 20, 511-516. http://dx.doi.org/10.1088/0143-0807/20/6/317

Olsen, R. V. (2001). A study of Norwegian upper secondary physics specialist conception of atomic models and wave particle duality. http://folk.uio.no/rolfvo/Publications/Tessaloniki_paper.pdf adresinden 23 Nisan 2014 tarihindeedinilmistir.

Ozcan, O. (2011). What are the students' mental models about the 'spin' and 'photon' concepts in modern physics?.Procedia Social and Behavioral Sciences, 15, 1372-1375. http://dx.doi.org/10.1016/j.sbspro.2011.03.295

Ozdemir, E., \& Erol, M. (2008). Student misconceptions relating wave packet and uncertainty principle in quantum physics. Balkan Physics Letters, Special Issue, 635-641.

Psillos, D., Koumaras, P., \& Tiberghien, A. (1988). Voltage presented as a primary concept in an introductory teaching sequence on DC circuits. International Journal of Science Education, 10(1), 29-43. http://dx.doi.org/10.1080/0950069880100104

Sadaghiani, H. R. (2005). Conceptual and mathematical barriers to students learning quantum mechanics. Unpublished doctoral thesis, Ohio State University.

Sanger, M.J., \& Greenbowe T.J. (1999). An analysis of college of chemistry textbooks as sources of misconceptions and errors in electrochemistry, Journal of Chemical Education, 76(6), 853-860. http://dx.doi.org/10.1021/ed074p819

Sanger, M.J. \& Greenbowe, T.J. (1997). Students' misconceptions in electrochemistry: current flow in electrolyte solutions and the salt bridge, Journal of Chemical Education, 74(7), 819-823.

Singh, C. (2001). Student understanding of quantum mechanics. Association of Physics Teachers, 69(8), 885-895. http://dx.doi.org/10.1119/1.1365404 
Singh, C., Belloni, M,. \& Christian, W. (2006). Improving students' understanding of quantum mechanics. Physics Today, 59(8), 43-49. http://dx.doi.org/10.1063/1.2349732

Steinberg, R., Wittman, M. C., Bao, L., \& Redish, E. F. (1999). The influence of student understanding of classical physics when learning quantum mechanics. http://www.physics.umd.edu/perg/qm/qmcourse/NewModel/research/qm_narst.pdf adresinden 23 Nisan 2014 tarihinde edinilmistir.

Styer, D. (1997). Teaching time development in quantum mechanics. A paper contributed to the meeting of the Ohio Section of the American Physical Society at Miami University, Oxford, Ohio.

Sen, A. İ. (2002). Fizik ogretmena daylarinin kuantum fiziginin temeli sayilan kavram ve olaylari degerlendirme bicimleri. Balikesir Universitesi Fen Bilimleri Enstitusu Dergisi, 4(1), 76-85.

Turgut, M. F., Baker, D., Cunningham, R., \& Piburn, M. (1997). Ilkogretim fen ogretimi. YÖK/DB Milli Egitimi Gelistirme Projesi Hizmet Oncesi Ogretmen Egitimi Yayinlari, Ankara.

Vadnere, R., \& Joshi, P. (2009). On analysis of the perceptions of standard 12 students regarding a physics concept using techniques of quantum mechanics. Physics Education, 26, 279-290.

Yesildag, F. (2009). Modern fizik ogretiminde ogrencilerin coklu modsal betimlemeleri algilamalari ve modsal betimlemelerle hazirladiklari yazma aktivitelerini degerlendirme surecinin ogrenmeye etkisi.Yayimlanmamis yuksek lisans tezi, Ataturk Universitesi, Erzurum.

Yildirim, A., \& Simsek, H. (2006). Sosyal bilimlerde nitel arastirma yontemleri. (6.bask1) Ankara: Seçkin Yayincilik.

Yildiz, A. (2009). Universite ogrencilerinin kuantum fizigi konularini anlama duzeyleri ve ogrenme amacli yazma aktivitelerinin akademik basariya etkisi.Yayimlanmamis doktora tezi, Ataturk Universitesi, Erzurum.

Yildiz, A., \& Buyukkasap, E. (2011a). Ogretmen adaylarinin Compton olayini anlama duzeyleri ve ogrenme amacli yazma aktivitelerinin akademik basariya etkisi.Uluslararası Insan Bilimleri Dergisi, 8(1), 1643-1664.

Yildiz, A., \& Buyukkasap, E. (2011b). Ogretmen adaylarinin fotoelektrik olayini anlama duzeyleri ve ogrenme amacli yazma aktivitelerinin akademik basariya etkisi. Kuram ve Uygulamada Eğitim Bilimleri, 11(4), 2259-2274.

Zhu, G. (2011). Improving students' understanding of quantum mechanics.Unpublished doctoral thesis, University of Pittsburgh. 